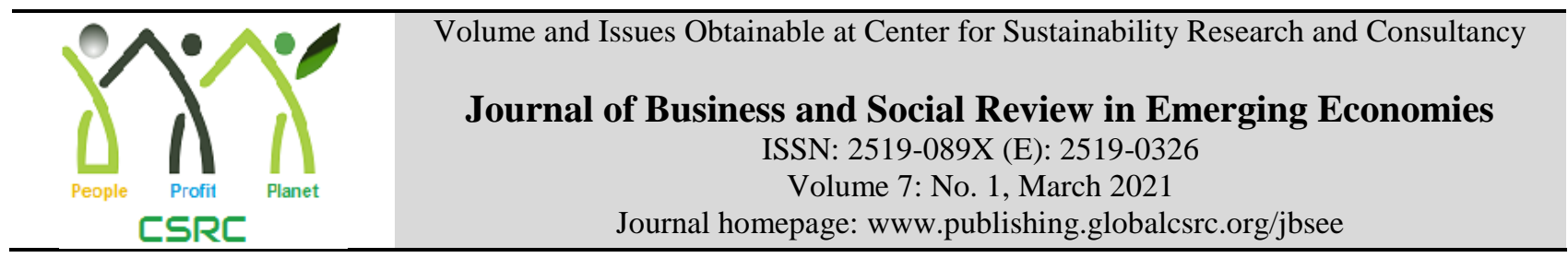

\title{
Need for Parents Training on Educational Aspects for Improving Parental Involvement in their Child's Education
}

\author{
*Shaheen Pasha, Department of Special Education, University of Education, Lahore, Pakistan \\ Shakeela Shah, Faculty of Education, University of Sindh, Jamshoro, Pakistan \\ Maimona Ijaz, Department of Special Education, University of Education, Lahore, Pakistan
}

*Corresponding author's email address: drshaheen.pasha@ue.edu.pk

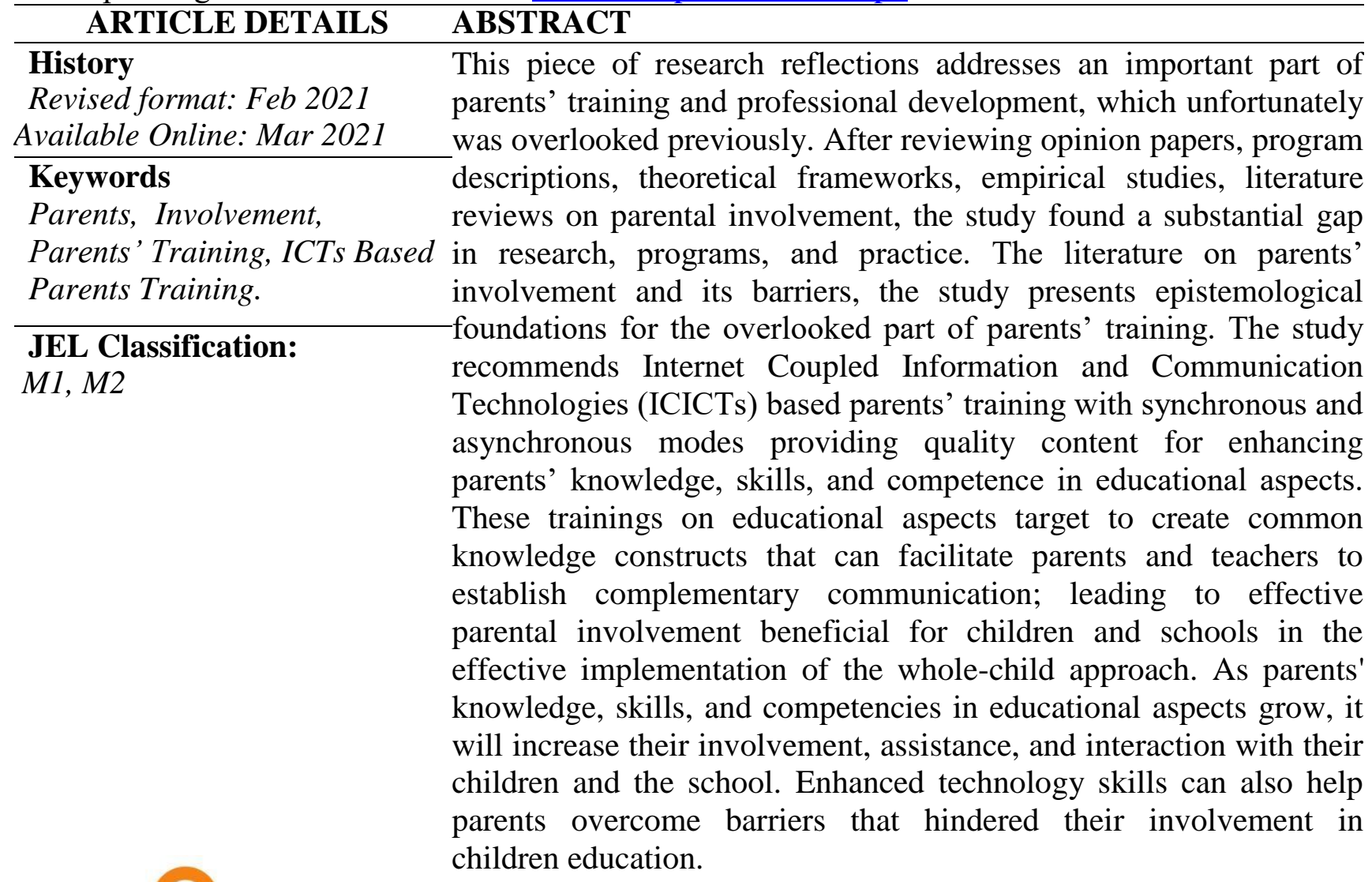

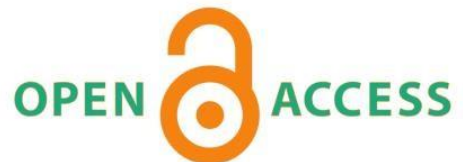

(C) 2021 The authors, under a Creative Commons Attribution-

NonCommercial 4.0

\begin{abstract}
Recommended citation: Pasha, S., Shah, S. \& Ijaz, M. (2021). Need for Parents Training on Educational Aspects for Improving Parental Involvement in their Child's Education. Journal of Business and Social Review in Emerging Economies, 7(1), 183-194.
\end{abstract}

\section{Introduction}

The importance of a symbiotic relationship between parents and school, and parents' involvement in their children's education has already been reported in many studies (Carpentier \& Lall, 2005; Harvard Family Research Project, 2014; Jeynes, 2016; Ashraf, 2019; DEEW, 2020). However, much of the work, has been observed, tend to be pre-assumed that parents are having all the necessary skills which 
are required to make their involvement effective for children's overall achievements. Parents are assumed to be responsible for providing a healthy and enabling environment for the physical and intellectual growth of children. The children should be demonstrating good social and emotional values, showing positive ambitions for personal fulfillment, a strong attitude towards monitoring, assisting and participating in educational aspects of their children (Desforges and Abouchaar, 2003; HFRP, 2014; DEEW, 2020). It is also assumed that parents have the appropriate knowledge to identify and meet the intellectual and developmental needs of their children. It has rarely been discussed how and from where parents have learned to identify and respond appropriately to children's needs; especially when children are with special needs.

Two other points attract attention. First, INTO (1997) has recorded that children spend $15 \%$ of their waking time at school. While they spent $85 \%$ of their waking time in other activities outside school or at home. Most of their waking time children spend at home (Ihmeideh and Oliemat, 2015). Parents' knowledge, skills, and competence in parenthood and educational aspects would, therefore, be considered essential to the overall development of children, including mental and physical development. Second, the International Classification of Functioning, Disability, and Health (WHO, 2001) has defined disability as the product of a complex relationship between an individual's state of health, personal factors, and the external environmental factors in which he or she lives. ICF recognizes disability as impairments of body functions, limitations in activities, and restrictions in participation (WHO, 2001). It also ensures that the needs of the children must be assessed and handled in the light of their physical, social, and attitudinal factors. For example, some children could be physically or mentally healthy but may face some form of activity limitations or participation restrictions (Clemente, 2017).

In recent studies, the whole-child approach to education has been suggested as an effective approach to child education (Hanover Research, 2015). In this approach, every child's health, safety, engagement, and self-esteem is ensured. It also sets standards for consistent, sustainable school performance and encourages long-term student achievement (Slade and Griffith, 2013). Nevertheless, it demands an awareness of children's strengths, weaknesses, needs, requirements, and vulnerabilities. In case of the whole-child approach, parents are expected to have a detailed awareness of the vulnerabilities, strengths, and needs of their children.

In the light of above discussion, parents, as major shareholders of the children waking time, need to have sufficient knowledge, skills, and competencies to identify and recognize strengths, weaknesses, and needs of their children to help in educational processes, impairments, activity limitations or participation restrictions. It would be expected that parents with these expertise, skills, and abilities should be in a position to provide their children with sufficient assistance. It would make their involvement successful and beneficial. Unfortunately, parents lack this knowledge, expertise, competency and often face difficulties in recognizing and performing their responsibilities appropriately. (Barth, et al., 2005; Clemente, 2017). Consequently, they are criticized for their inadequate parental involvement (Hornby and Blackwell,2018).

In this study, an overlooked dimension of parents' training that has never been discussed in the way that researcher have pointed out. It is agreed that parenting and education are two separate but complementary aspects of children's lives. Parents' training in guidance, counseling, and parenting has already been recommended in the most recent researches (Lundahl, Risser, and Lovejoy, 2006; Elijah, 2011). However, parents' training in the area of educational aspects has always been overlooked. The lack of formal knowledge, skills, and competence of parents concerning educational processes, school language, instructional methods, pedagogical strategies, assessment and evaluation mechanisms, the whole child approach in an inclusive environment, technology and its usage, research and evidencebased practices on parent participation, etc. would be considered as a primary cause of frustration or one of the key barrier in their effective involvement. 
After reviewing the literature on parents' involvement, the study has put forward some recommendations and useful ways for parents' training and professional development in educational aspects to overcome the barriers of their effective involvement. The concluding remarks are set out in the last section. The study uses the term 'parents' to refer to parents, families, and caregivers. Similarly, the term 'involvement' is often used to refer to 'coordination' and 'participation.

\section{Parent Involvement}

In 1990, a consortium of international organizations such as the World Bank, UNESCO, UNICEF, UNDP, and 155 countries produced a landmark declaration that draws global attention to the fact that full inclusion of people with special needs is the primary pillar of the global human rights education agenda (UNESDOC, 1990). In literature, the Whole-child approach to education has been advocated for meeting the distinguishing talents, desires, needs, and preferences of children (Darling-Hammond and Cook-Harvey, 2018). The approach not only promotes children's social, emotional, and academic skills but also offers a sense of security, emotional closeness, wellbeing and realistic learning opportunities that enable children to learn effectively. However, the importance of the school environment could not be overlooked or undermined because it offers a platform for children's overall development (DarlingHammond and Cook-Harvey, 2018; Godstime and Joseph, 2019).

Children's education has always been a key concern of both parents and schools. Parents are considered as initial educators of their children's overall progress (Weiss, et. al, 2009; Markow and Cooper, 2012). Schools are considered responsible for fostering the sense of well-being of students at all levels of education; during and after school years (DEEW, 2020). Teachers, as Paula \& Winters (1998) have said, are supposed to educate parents about learning targets and helping children at home to achieve these targets. A good cooperative and collaborative relationship between parents, schools, and teachers has always been recommended for children's development and academic success. Recent studies have advocated that reciprocal trust and respect between schools and parents boost children's overall achievements (Henderson and Mapp, 2002; Epstein, 2009; HFRP, 2014; Jeynes, 2016; Durisic and Bunijevac, 2017; Lara and Saracostti, 2019).

Markow and Martin's (2012) survey has found a positive attitude among teachers towards parents' involvement in educational processes. Regardless of parents' educational background, socio-economic conditions, ethnicity, marital status, and age, the significance, and effect of parenthood on children's educational achievements have reported in other studies as well (Henderson and Mapp, 2002; Epstein, 2009; Durisic and Bunijevac, 2017). In their meta-analysis of 51 studies on school-family-community relationships between 1993 and 2002, Henderson and Mapp (2002) have reported that children's academic success in terms of grade, class attendance, social and behavioral aspects have improved through parents' involvement.

Teachers' and school administration's attitude, behavior, and practices of interacting with parents have been identified important factors affecting parents' attitude towards their children's education (Epstein, 2009). Markow and Pieters (2012) have mentioned that many teachers consider a healthy and trustworthy parent-school relationship, promotes children's overall development and parents' involvement. Parents' assistance to their children has also been reported as an important factor enabling children to succeed more in their academic achievements (Suizzo, 2007).

The studies conducted in the Pakistani context also display positive results of parents' involvement. For example, Rafiq, et al.'s (2013) and Shah and Anwar's (2014) researches in secondary schools have reported that parents' involvement encourages children to perform better. Shafiq (2015) has reported that parental participation made children comfortable and able to strive for the best. Qayyum, et al. (2015) have accounted that parents' active involvement helps their children improve their behavior. Similarly, parents' self-efficacy and their responses to school invitations are two factors affecting parental involvement. However, Ahmed, Sana, and Butt (2019) have reported that many schools have a lack of 
policies and strategies regarding parental involvement and communicating with teachers. Similarly, the study of 600 students studying in various secondary schools has reported parents' involvement as a crucial factor in children's overall achievements (Jamil, et al., 2011). Shahid and Iqbal (2018) have reported effective parent involvement as an important factor in teacher wellbeing and job satisfaction in achieving their personal and professional goals.

\section{Barriers to Parents' Involvement}

Since 1990, parents' role in childhood education has been a topic of great concern among policymakers, scholars, and professional teaching organizations (Henderson \& Mapp, 2002; GOALS2000). Nevertheless, establishing meaningful parents' involvement remains a challenging task. It requires professional expertise, skills, attitudes, dedication, patience, and awareness of the other dynamics of family involvement (Epstein, 2009; Durisic and Bunijevac, 2017). In literature, multiple barriers to parents' involvement have been identified. For example, in his study, Ashraf (2019) stated that parents did not feel welcome and received little guidance that led to misunderstanding and in-effective communication between school and parents. Language, communication (information flow), and parents' work schedules often discourage parents from involving in school activities (Baker and Soden, 2016). In their review, Hornby and Blackwell (2018) have reported some other barriers like: lack of parental involvement in participation when encouraged to do so; lack of school administration support; stereotype attitude of teachers that parents are not qualified to do so, lack of support from educational decision-makers; parents' concern for the stresses and demands of everyday life including financial and employment-related issues, and language barriers; parents' fixed working schedule, financial and transportation issues, and underprivileged neighborhoods; parent's stereotype ideas and cultural norms, financial constraints, and low educational background; lack of confidence due to less educational experiences; parents' bad educational experiences and weak social capital; the burden of single parenthood and the unwelcoming attitude of school towards single-parents; time conflicts and a lack of resources; scheduling conflicts with older siblings; feeling nervous about going to school due to parents' personal experiences; lack of communication skills among parents; Parents' low qualification; parents' personal lives conflict, social anxieties; lack of teachers training regarding supporting the family holistically.

\section{Parents' Incapacity/Disability}

Parents' involvement has often been seen in the context of guidance, counseling, information exchange, physical assistance, or sharing of concerns (Baeck, 2010; Jeynes, 2016; DEEW, 2020). In the case of inappropriate outcomes, attitude, or actions of children, parents are informed but evasively made accountable by declaring ineffective parent involvement as a key obstacle. The study has noticed that teachers, shareholders of $15 \%$ of children's wake-up time, are provided with numerous opportunities for vocational/professional training in children's education. Whereas parents, shareholders of $85 \%$ of children's wake-up time, seldom have opportunities for vocational or professional training related to children's educational aspects. As a result, they are lacking knowledge, skills, and competence in educational aspects; affecting their involvement and communication with schools, teachers, and even with their children. It may be a compelling point that teachers are professionals with a specific academic background and professional knowledge that parents do not have. Also, parents' circle of influence is different from that of teachers, so parents do not need to be prepared as teachers are. But, if parents are regarded as shareholders of $85 \%$ of children's wake-up time, then this stereotype thought may need a paradigm shift.

Parent training programs offered in various countries concentrate mainly on child maltreatment parenting techniques and welfare services (Barth, et al., 2005). Also, the effectiveness of such training has seldom been tested (USDHHS, 2009). Many researchers have reviewed and proposed guidelines to improve parents' training, delivery methods, and training contents (Harris and Goodall, 2006; Lewin and Luckin, 2010). However, the main emphasis of these guidelines is to improve parenting techniques and welfare services. 
The importance of such training could not be undermined. However, a promising whole-child approach in an inclusive environment requires parents to be fully trained. Parents need such trainings that would improve their knowledge, skills, and competence on how to carry out educational processes and activities at home, how to help children to overcome their activity limitations and participation restrictions. Any such opportunity would help them surmount the barriers they face regarding their involvement.

\section{Theoretical Foundation of the Study}

Children's learning is an interesting area of research. Constructivism associates learning with human biological processes, including their mind, developmental processes, and cognitive structures. Constructivist believes that learners' knowledge and understanding is based on their own experiences. In his theory of cognitive development, Jean Piaget (1971), emphasizes that children make meaning concerning the interaction between their experiences and ideas. Learning is, therefore, achieved by constructing knowledge out of experiences. Piaget's theory puts emphasis only on biological aspects. Whereas, Lev Vygotsky's (1962) theory of social constructivism realizes the significance of sociocultural learning. He has identified both societal (nurture) and biological (nature) factors as the primary pillars of human learning.

Communication is an important factor in learning and an important aspect of humans' life. As a member of human society, we have a biological obligation to interactor/ communicate with others (Ruesch and Batesonhave, 1951, p. 7). The communication theory of Watzlawick and his colleagues have clarified the symmetry of communication. They have argued that all communications are either symmetrical or complementary. A communication based on equality is complementary, whereas, mutual differences generate symmetrical Communications. (Watzlawick, et al., 1967, P70).

The relationship between school staff and parents depends on their communication. In the light of Watzlawick et al. (1967) communication theory, if the parents face any kind of differences with teachers which may be social, economic, cultural, religious, intellectual, etc., the communication would be symmetrical; transpiring misunderstanding and empathy issues. As a result, parents would begin to experience anxiety, self-doubt, discrimination, low self-esteem, etc. And, if they feel equality, their communication is complementary, the parents would feel comfortable, confident, secure, and encouraged; they may find themselves in a position to cope with the barriers they face.

If the target of parent involvement is to increase children's learning and, according to socio-cultural learning, social factors are just as important as children's biological factors, then teachers and parents could be considered as the essential constituents of children's biological and social factors. If the learning opportunities for both teachers and parents are designed to create some common knowledge constructs, then they will be in a position to establish complementary communication. Such complementary communication would encourage parents for their involvement which would be beneficial for children's learning and implementation of the whole-child approach.

The concept of empathy is also very important in this research. It is believed that empathy is a process that can make the involvement of parents more meaningful and effective. Nonetheless, the concept of empathy is usually misunderstood and used in terms of sympathy, compassion, pity, identification, and self-transposal, etc. In this research, a phenomenological definition of empathy is adopted, which was proposed by Edith Stein (1970), which describes it as an unteachable trait of helping to promote attitudes and behaviors. He further argues that the process of empathy cannot be forced to happen, but can be facilitated, interrupted, or blocked through our attitude and behavior.

Rogers (1975), the founder of client-centered therapy, has declared unconditional positive regard, active listening, the sensitivity of feelings and thoughts as important pre-requisite for developing empathy. In the parents' involvement, it is assumed that the parent-teacher relationship resembles the therapist- 
clients relationship. When teachers actively listen to parents, treat them with compassion, and re-report their thoughts and feelings with sensitivity and precision, there will be a sense of empathy that not only develops empathy but also improves parents' self-efficacy. As a result, parents may increase their trust in their abilities to perform activities that are required to achieve particular results or outcomes.

The importance of parents' role in children's education could not be denied. However, it draws attention towards an important point which has provided the epistemological foundation and the necessary impetus for the conceptual framework of this study. Researcher has already discussed that children spend $15 \%$ of their waking time with teachers, while they spend their remaining waking time outside the school, mainly at home. This ensures that the quality of education for children depends on the knowledge, skills, competence, attitudes, and practices of both actors; actors with $15 \%$ of waking timeshare (teachers) and actors with $85 \%$ of waking timeshare (parents) (Tatlah,2015). A competent and well-performing teacher has always been demanded in educational settings. But, a competent and wellprepared parent has never been acknowledged as the second most important resource of any educational setting.

Education is a continuous and dynamic process, so ongoing regular training programs will be needed to improve and refresh the knowledge, skills, competence, attitudes, and practices on educational aspects, including curriculum content, teaching-learning practices, evidence-based research findings on inclusive education, online educational tools and technologies, the latest innovations in assistive technology, the latest research on assessment and evaluation, etc.

\section{Discussion and Conclusion}

We are living in the era of Net Generation (Tapscott, 1998) in which the type of social interaction is rapidly evolving; offering both positive and negative features. The use of Internet Coupled Information and Communication Technologies (ICICTs) has provided unparalleled opportunities to fostering the information flow between school and parents, particularly for parents having children with special needs. ICICTs allow parents to access information about children's study literature, grades, expectations, homework, due dates, progress, and so on, they would feel more comfortable and encouraged, interacting and working with school staff and their children (Lewin and Luckin, 2010); particularly those parents who are facing time, schedule, or mobility barriers (Becker, 2007; Zieger and Tan, 2012).

It is believed that parenting and education are two different but complementary elements of children's life. Parenthood is an important skill, and parents training on this aspect has also been suggested in the literature (Lundahl, Risser, and Lovejoy, 2006). Parents' guidance and counseling to recognize their children's educational needs have already been recommended (Fan and Chen, 2001; Elijah, 2011; Dughi, Dughi, Tatlah,2014; and Juncu, 2020). Nevertheless, our focus in this study is not only on guidance and counseling, rather on parents' training in the area of educational aspects.

As a common practice, teachers are expected to enter the teaching profession after completing formal technical/professional training or experience. Contrarily, parents have no such opportunity to receive such formal training. The lack of formal technical/professional training or experience of parents concerning educational aspects can be considered a primary source of frustration or a barrier to their involvement. Researcher believes that parents also need training on educational aspects, like instructional methods, pedagogical strategies, assessment and evaluation mechanisms, the whole child approach in an inclusive environment, technology and its usage, etc.

After reviewing opinion papers, program descriptions, theoretical frameworks, empirical studies, literature reviews on parental involvement, the study found a substantial gap in research, programs, and practice. The study has found that parents, as $85 \%$ shareholders of children waking time, need training that could strengthen their knowledge, skills, and competencies on both nature (development) and 
nurturing (education) aspects of children's lives, pedagogical strategies, assessment and evaluation mechanisms, the whole child approach in an inclusive environment, technology and its usage, research and evidence-based practices on parent participation, etc.

Over the last few years, studies have shown that ICICTs can be used to improve home-school interaction through the use of easy, efficient, and effective means of multimedia information exchange. In contrast to personal interaction and print media sharing, which are slow, expensive, and involve many sociocultural and psychological barriers, ICICT-based training offers fast, efficient, synchronous, and asynchronous means of communication, information sharing, and a self-paced learning environment. In particular, the asynchronous mode of training and communication provides an opportunity to encourage and engage parents who are faced with time, schedule, travel, and financial barriers. While the study has recommended that parent's ICICTs based training on the educational aspects would be a flexible and cost-effective solution, the quality of contents and delivery methods should be the prerequisite for achieving the goal of enhancing parents' trust, confidence, participation, and interest. Failure to do so would give rise to misperceptions, mistrust, and lack of confidence, particularly among parents of special needs children studying in an inclusive environment. School administrators, service leaders, professionals, and other support organizations would also recognize key aspects and use both researchbased and evidence-based key messages in the design of the activities, methods, and content of such online training. Schools and other support agencies must ensure that parents have access to and acquaintance with technology and that parents find training valuable and useful.

It is believed that embracing the potential of ICICTs for parent education in both nature (development) and nurturing (education) aspects of children's lives would make parents productive members of the education system, adding value to the adoption of the whole-child approach in an inclusive environment. As parents' knowledge, skills, and competencies in educational aspects expand, it will be imperative to increase their involvement, assistance, and interaction with the school and their children.

\section{Recommendations}

This study recommends that parents must be provided with training opportunities that should cover both theoretical and practical aspects and promote parents' knowledge, skills, and competence on both Nature (development) and Nurturing (educational) aspects of children's life. It is also recommended that such trainings should be conducted using ICICTs, both in synchronous and asynchronous modes so that parents can access the training material anytime they want and communicate with school or teachers through networking tools such as e-mails and social media (Lunts, 2003). The training will also offer online interactive elements as well as live practice sessions through which parents could see the execution of the teaching techniques, ask questions, and participate in self-reflection. It is believed such trainings and professional development programs will, on the one hand, allow parents to overcome their barriers and on the other hand, prepare them to promote creative, advantageous, and efficient involvement.

The study recommends that parents' formal technical/professional training initiatives should aim to help parents to develop positive attitudes, perceptions, and beliefs towards their role in the educational aspects of their children. However, despite optimistic goals, parents' training programs cannot improve their mindset if the training material is of low quality with minimal relevance and is implemented ineffectively. Quality training programs would make parents able to support their children, spend quality time with them, avoid harsh punishment, and make effective communication (Stolz, 2011). It is believed that increased parents' professional knowledge, skills, and competence in educational aspects would allow children to learn in a variety of circumstances and environments.

In addition to educational training, the schools should also develop special ICICTs based training on school's language, schools' targets, operating procedures, school parental involvement strategy, and how parent involvement work in the whole school approach in an inclusive environment. The school staff 
must also have awareness about the training. It is also recommended that schools and other supporting agencies develop special ICICTs based training for parents of special needs children studying in inclusive environments.

The study also recommends that the ICICTs based training would offer a flexible and cost-effective solution but just developing training to provide information may flourish misperceptions, distrust, and lack of confidence particularly among those parents who are having children with special needs. Therefore, the schools and other supporting agencies must ensure that parents have access to and acquaintance with the technology and parents find training valuable and useful. Continuous monitoring, evaluating and feedback system would be required to maintain the interest of parents. The schools and other supporting agencies are suggested to develop an operational strategy on these aspects.

\section{References}

Ahmed, A. \& Sana, \& Butt, M.. (2019). Parents Involvement in Their Children Educational Achievement: A Study of Undergraduate Students. Available at https://www.researchgate.net/publication/330133868_Parents_Involvement_in Their Children Educational Achievement: A Study of Undergraduate Students

Ashraf, S. (2019). Pakistani parents and their children's school: parent and school staff perspectives on parental involvement at the foundation stage. Journal of Race Ethnicity and Education, 22(5): 703-721.

Baeck, U. D. K. (2010). Parental involvement practices in formalized home-school cooperation. Scandinavian Journal of Educational Research, 54(6): 549-563.

Baker, A. \& Soden, L. (2016). The Challenges of Parent Involvement Research. National Council of Jewish Women Center for the Child. Available at https://teensparentsteachers.org/the-challengesof-parent-involvement- research/

Barth, R. P., et al. (2005). Parent-training programs in child welfare services: Planning for a more evidence-based approach to serving biological parents. Research on Social Work Practices, 15(5): 353-371. https://doi.org/10.1177/1049731505276321

Becker, J. D. (2007). Mind the gaps: Exploring the use of technology to facilitate parental involvement, particularly for historically underserved populations. Journal of School Public Relations, 28: $57-82$.

Carpentier, V. \& Lall, M. (2005). Review of Successful Parental Involvement Practice for 'Hard to Reach' Parents. London, Institution of Education, University of London.

Clemente, I. (2017). Barriers and facilitators to participation in physical activity for children with disabilities. Master Thesis, School of Education and Communication (HLK), Jönköping University.

Darling-Hammond, L. \& Cook-Harvey, C. M. (2018). Educating the Whole Child: Improving School Climate to Support Student Success. Learning Policy Institute. Available at https://learningpolicyinstitute.org/sites/default/files/product-

files/Educating_Whole_Child_REPORT.pdf

DEEW (2020). Family - School Partnerships Framework: A guide for schools and Department of Education, Employment, and Workplace Relations. Australian

families, Available at http://www.familyschool.org.au/files/3013/8451/8364/Familyschool_partnerships_framework.pdf

Desforges, C. \& Alberto, A. (2003). The impact of parental involvement, parental support and family education on pupil achievement and adjustment: A literature review. Research Report , No.433. Queen's Printer, No.33.

Dughi,T., Dughi, D., \& Juncu, M. (2020). Parental Counseling and the Education of Children with Special Educational Needs. Available https://pdfs.semanticscholar.org/e620/5b3b29567ade45a5735bc1a86ee9b2e4c d33.pdf

Durisic, M. \& Bunijevac, M. (2017). Parental Involvement as an Important Factor for Successful Education. C. E. P. S. Journal, 7(3): 137-153. 
Elijah, K.( 2011). Meeting the guidance and counseling needs of gifted students in school settings. Journal of School Counseling, 9: 3-19.

Epstein, J. L. (2009). In School, family, and community partnerships: Your handbook for action (3rd Ed.). USA: Corwin Press.

Fan, X. \& Chen, M. (2001). Parental Involvement and Students' Academic $\quad$ Achievement: $\quad$ A Meta-Analysis. Educational Psychology Review,13: 1-22. 10.1023/A:1009048817385.

Fan, W., Li, N. \& Sandoval, J. R. (2018). A reformulated model of barriers to parental involvement in education: comment on Hornby and Lafaele (2011), Educational Review, 70(1): 120127, DOI: $10.1080 / 00131911.2018 .1388614$

Godstime, T. C. \&Joseph, A. O.(2019). Influence of School Environment on Students' Academic Performance in Technical Colleges in Rivers State. International Journal of New Technology and Research, 5(3): 40-48.

GOALS2000: Educate America Act, available at https://www2.ed.gov/legislation/GOALS2000/TheAct/index.html

Hanover Research (2015). Best practices in whole child education: prepared for Arlington public schools. https://www.apsva.us/wp- content/uploads/2018/10/Best-Practices-in-Whole-ChildEducation-Arlington- Public-Schools.pdf

Harris, A. and J. Goodall (2006). Removing Obstacles: Achieving Inclusive Approach to Parental Engagement. Curriculum Briefing, 5(1): $17-19$.

HFRP (2014). Harvard Family Research Project. Redefining family engagement for student success. Retrieved from http://www.hfrp.org/ family-involvement/publications-resources/redefining-family-engagementfor- $\quad$ studentsuccess

Henderson, A., \& Mapp, K. L. (2002). A new wave of evidence: The impact of school, family, and community connections on student achievement. Annual synthesis. Austin, TX: National Center for Family and Community Connections with Schools, Southwest Educational Development Laboratory.

Hornby, G. \& Blackwell, I.(2018). Barriers to parental involvement in education: an update, Educational Review, 70(1):109-119, DOI:10.1080/00131911.2018.1388612.

Ihmeideh, F. \& Oliemat, E. (2015). The effectiveness of family involvement in early childhood programmes: perceptions of kindergarten principals and teachers. Early Child Development and Care, 185(2):181-197, DOI:10.1080/03004430.2014.915817

INTO (1997). Parental involvement: Possibilities for Partnership. Irish National Teachers' Organization, Dublin: INTO.

Jamil, A., Atta, M. A., Baloch, J., Danish, E., Younis, M. \& Siddiq, S. (2011). Academic Involvement of Parents and its Relationship with Educational Attainments of Secondary School Students. World Applied Sciences Journal, 12 (9): 1409-1412.

Jeynes, W. H. (2016). A Meta-Analysis: the relationship between parental involvement and Latino student outcomes. Education and Urban Society, 49(1):4-28. doi: 10.1177/0013124516630596

Lara, L. \& Saracostti, M. (2019). Effect of Parental Involvement on Children's Academic Achievement in Chile. Frontiers in Psychology, 10,1464. DOI $=10.3389 /$ fpsyg.2019.01464. https://www.frontiersin.org/articles/10.3389/fpsyg.2019.01464/full

Lewin, C, \& Luckin, R., (2010). Technology to Support Parental Engagement in Elemenary Education: Lessons Learned from the UK. Computers and Education, 54 (3): 749-758.

Lunts, E. (2003). Parental involvement in children's education: Connecting family and school by using telecommunication technologies. Meridian: A Middle School Computer Technologies Journal, 6(1): 1- 8 .

Lundahl, B. W., Risser, H. J., \& Lovejoy, M. C. (2006). A meta-analysis of parent training: Moderators and follow-up effects. Clinical Psychology Review, 26: $\quad$ 86-104.

Markow, D., \& Pieters, A. (2012). The MetLife survey of the American teacher: Teachers, parents and the $\quad$ economy, Available at https://www.metlife.com/assets/cao/contributions/foundation/american- teacher/MetLife- 
Teacher-Survey-2011.pdf

Piaget, J. (1971). Psychology and Epistemology: Towards a Theory of Knowledge, $\quad$ New $\quad$ York: Grossman.

Paula, N., \& Winters, K. (Eds.). (1998). Teachers leading the way: Voices from the National Teacher Forum. Washington, DC: U.S. Department of Education.

Qayyum, A., Madiha, C., Khaliq, A., Agha, Q. \& Hassan, S. M. (2015). Parent's Involvement in their Child Academic Achievement. Pakistan Vision. 16: 117- 125.

Rafiq, M. W., Fatima, T., Sohail, M. M., Saleem, M. \& Khan, M. A. (2013). Parental Involvement and Academic Achievement; A Study on Secondary School Students of Lahore, Pakistan. International Journal of Humanities and Social Science, 3(8): 209-223.

Tatlah, I. A. (2015). Effect of leadership behaviour and school organizational health on students'achievement. Lahore: (Unpublished Doctoral Thesis) University of Management and Technology, Lahore.

Tatlah, I. A., Iqbal, M. Z., Amin, M., \& Quraishi, U. Q. (2014). Effect of leadership

behaviour of principals on students' academic achievement at secondary level: A comparison of leaders and teachers perceptions. Journal of Research and Reflections in Education, 1-12.

Rogers, C.R. (1975). Empathic: An unappreciated way of being. Couns psychologist, 1(1).

Ruesch, J. \& Bateson, G. (1951), Communication: The Social Matrix of Psychiatry, Ｗ.W. Norton \&Company, New York, 1987.

Shafiq, F. (2015). A Study of Parental Engagement Among Pakistani Families, A thesis submitted for the degree of Doctorate in Education, Faculty of Humanities, School of Environment, Education and Development. University of Manchester.

Shah, M. A. \& Anwar, M. (2014). Impact of Parent's Education and Involvement on Children Performance in Southern Punjab Pakistan. International Journal of Research, 1(5): 172-180.

Shahid, M. S. \& Iqbal, M. (2018) The Effect of Parental Involvement in School Decision Making on Morale of Elementary School Teachers. Journal of Elementary Education, 21(1):1-9.

Stein, E. (1970). On the Problem of Empathy, 2nd ed. The Hague, Netherlands, Martinus Nijhoff.

Slade, S. \& Griffith, D. (2013). A whole child approach to student success. KEDI Journal of Educational Policy. 21-35.

Stolz, H. (2011). Parenting Education. In book: Family life education: Principles and practices for effective outreach, Edition: 2nd, Chapter: Parenting Education, $\quad$ Publisher: $\quad$ Sage, $\quad$ Editors: Stephen Duncan, Wallace Goddard, 191-210.

Suizzo, M. (2007). Home based parental involvement in young children's education: Examining the effects of maternal education across U.S. ethnic groups. Educational Psychology, 27(2): 124.

Tapscott, D. (1998). Growing up digital: The rise of the net generation. New York, NY: McGraw Hill. USDHHS(2009). Parent training Programs: insight for Practitioners, U.S. Department of Health and Human Services Centers for Disease control and Prevention. Available https://www.cdc.gov/violenceprevention/pdf/parent_training_brief-a.pdf

Vygotsky, L. S. (1962). Thought and language. Cambridge, MA: MIT Press.

Weiss, H. B., Little, P. M. D., Bouffard, S., Deschenes, S. N., \& Malone, H. J. (2009). The federal role in out of school learning: After-school, summer learning, and family involvement as critical learning supports. Cambridge, MA: Harvard Family Research Project.

Watzlawick, P.; Beavin, J. H. u. Jackson, D. D. (1967). Pragmatics of Human Communication, .W. Norton \& Company, New York.

WHO (2001). International classification of functioning, disability and health. Available at https://apps.who.int/gb/archive/pdf_files/WHA54/ea54r21.pdf?ua=1

Zeiger, L. B., \& Tan, J. (2012). Improving parent involvement in secondary schools through communication technology. Journal of Literacy and Technology, 13: $\quad 30-54$. 
